\title{
PSYCHE.
}

\section{SOME OLD CORRESPONDENCE BETWEEN HARRIS, SAY AND PICKERING.-III.}

\author{
[HARRIS TO SAY.] \\ Milton (Mass.) Nov'r 18, 1824. \\ To Thomas Say, Esq. \\ Dear Sir, \\ I have waited until
}

this for a private conveyance of the box of insects which accompanies this letter.

The numbers of your Journal which I have received have afforded me much gratification, particularly the papers by yourself and those by Mr. Charles Bonaparte. From your descriptions I have already recognized several of my insects, \& probably shall more when I can find leisure to examine them. The last number of the Journal wh. I have received is that for August; \& I shall be glad to have any numbers that have since appeared sent me by the gentleman to whom I have entrusted this letter \& box. I have requested $\mathrm{Mr}$. Fuller to procure for me the first volume of your American Entomology, from which I anticipate much information \& pleasure. If the work is published by subscription I should be happy to use my endeavours to procure subscribers for you.

I am completely at a loss for the description of that weevil which, in your letter of the 26th May, you call the pinastri of Fabricius. The same specific name occurs in Melsheimer's catalogue; but I find no species by that name in the works of Fabricius which I possess: These are his Entomologia Systematica, 5 vols. I 792-1 798; \& his Systema Eleutheratorum, S. Rhyngotorum, S. Piezatorum, \& S. Antliatorum, 5 vols. $1801-1805$. Neither does the specific name pinastri occur in Gmelin's Linné.

Curculio Nenuphar Herbst I do not find in Fabr. or Gmelin, \& have not access to the work of Herbst.

I must thank you to refer me to the number of the Journal Acad. Nat. Sc. in which your description of Stenocorus tridens is to be found.

Last September I was so fortunate as to discover the male of that species of Aegeria of which I sent you the female in the spring, \& to wh. I gave the name of fulvicornis, in a former letter. After repeating my definition of the species I will, agreeably to your request, add the characters of the male. Aegeria (fulvicornis) brunnea, alis posticis hyalinis; margine postico, stigmateque costali fuliginoso ; antennis tarsisque fulvis, abdomine barbato. Mas minor, alis anticis basi hyalinis, apice opacis; ano tribarbato, barba media perlonga, fulva. The most remarkable characteristic of 
the male is the extremely long, slender, bearded appendage to the abdomen, of a tawny or dirty yellow colour. The whole length of the male from the head to the extremity of this appendage is $\frac{8}{10}$ of an inch ; this appendage is not quite $1^{4}$ of an inch; beirg nearly as long as the whole body. Standing obliquely on each side of the anus is a little fuliginous tuft. The abdomen is somewhat fulvous beneath. The anterior \& intermediate extremities are fulvous, the latter however have a dark patch on the genicula \& tibiæ. The first joint of the posterior tarsus is much more pilose than in the female; the hair near the union of the tarsus \& tibia is fuliginous, the remainder fulvous. The pectinations of the antennæ are slightly fuscous. This is the only male that I have ever seen, \& I found it on the identical currant bush from which I had the preceding year taken the females.

I have this season met with a species of Cicindela that is new to me, $\&$ which I cannot identify as any one of those described by you in the Trans. Am. Philos. Soc. Phila. I8r8. I have called it Cicindela (erythrogaster)* obscure fusca, elytris lunulis basi et apicis, fascia intermedia flexuosa, punctisque duobus albidis : abdomine femoribusque viridis; ano late rufo. Length half an inch. Antennæ green at base. Head cupreous, with two green abbreviated lines between the eyes. Mandibles white at the base, black at the points. Lip white, with a single tooth. Thorax cupreous obscure, with the margin \& breast green. Elytra obs[c]ure, some-

*[See Harris, Entom. corresp., p. 2.] what cupreous, with a humeral \& terminal lunule, an intermediate flexuous band, \& two spots behind the band whitish. Abdomen green, the hypogastrium red. Feet obscure, thighs green. I have only met with one specimen, which was captured in a dry, gravelly pasture.

Prof. Peck taught me to define the species in Latin \& I have generally adhered to his advice, though it savours somewhat of pedantry.

My friend, Mr. Fuller, has kindly taken charge of a package containing two boxes of insects for you. In box I, (the bottom one) are some of the Coleoptera which I have collected. They are all numbered in order to facilitate you in naming to me such as have been described, \& to enable you to indicate the nondescripts. I have kept a catalogue to correspond, with arbitrary names for all the species not as yet ascertained. From the want of books, plates, \& access to other cabinets, but more than all, from the want of time to examine them I have made out but few of the species. These I have added, however, that I might from your information and experience, render myself doubly sure; \& also that I might learn of you to what genera they are to be referred, according to the System of Dr. Leach in Brewster's Encyclop. I prefer on most accounts his system to that of Latreille in the Regne Animal of Cuvier. Should it however be inconvenient to you to follow the first, I must content myself with having the genera according to the second; with such synonyms as may be necessary. No. I of 
the Coleoptera I once supposed to be Cicindela trifasciata, F.; but now think it must be you[r] C. vulgaris. No. 7 is probably Brachinus fumans $\mathrm{F}$. No. 27 much resembles your Buprestis divaricata; but is evidently a distinct species, from the construction of the apex of the elytra. No. 37 is the luminous larva? of some Lampyris: it is very common in low grounds in Sept'r and Oct'r. Nos. 66, 67, 68, and 69 may perhaps be only sexual or other varieties of one species. The same may be true as to Nos. $136,137,138$, and i 39. No. $76 \mathrm{I}$ take to be your Melolontha pilosicollis; No. 83 your $M$. sericea ; \& No. 86 your Cetonia barbata. No. 93, as was observed by Prof. Peck, differs somewhat from the European Tenebrio molitor. No. 98 is to be found in all stages within the legumes of Baptisia (Sophora L.) tinctoria, in the months of Aug't and Sept'r. No. 106 inhabits beneath the bark of the Plum-tree; No. Io7 beneath that of the Juniperus virginiana and if they are not already described by some other name, should, according to a rule of Linnæus, bear for their specific designations the generic names of the trees which afford them sustenance. This rule I conceive to be of the highest importance; and it appears most proper to distinguish the species of insects by the names of the trees or plants on which they live, in every instance where it is practicable, or where the habitat is known.

Can you tell me where I am to look for the larva of No. I 4 , Lamia torna- tor, F. \& for that of No. II ? That of No. I 6 inhabits the Lombardy poplar. Can No. II 7 be Stenocorus cyaneus, F. ? Dr. Leach has separated from the genus Rhagium some insects to which he has given the generic name of Hargium; the characters of which are, "Thorax with a spine on each side; antenna thickest in the middle." The type of this genus is Rhagium indagator, F. Now it seems to me that No. I 7 might be referred to this genus. Please give me your opinion on the subject. No. I32 appears to be Cassida aurichalcea, F. but no mention is made, in the description of that species, of the small black spot on each elytron. I have written a paper on this insect for my friend Hon'l John Lowell. No. I 49 is extremely common on the Tilia americana, \& the English Elm.

In the second box No. I is a complete scare-sleep, and from its note is called "Katy-did." No. 20, Sigaraswims in the ordinary way, \& not upon its back. No. 21, Membracis bimaculatus ? F. is found in abundance on the Robinia pseudacacia in September. You may have observed the knotted condition of the small twigs of this tree. Each protuberance contains in summer a reddish worm, the larva of some insect, which lives on the pith, \& leaves the tree to go through its metamorphosis, probably in the ground. May it not be the larva of this species of Membracis. Do you know the oeconomy of No. 33 ? I have ascertained the metamorphosis of Nos. 34, 35, 36, 44, 
$45,46,47,48,49, \& 50$. The history of some of them, particularly the 5 or 6 last, is interesting to the agriculturist, etc. On the cover are 3 more Lepidoptera, with whose changes I have made myself acquainted; \& wish to be sure that I have ascertained the species. No. I29 I take to be Papilio Troilus, F., No. Izo P. asterias, F., \& No. I3 $P$. cardui, F. All three were raised from the young larvæ. No. 75 is the parasite of Papilio Asterias. I have sent but few specimens of the Order Lepidoptera, because they are large, and occupy too much room.

Do you know the larva of Papilio Hyale ? \& its habitat? Of Diptera the box contains but 3 species. The Myopa $\&$ Asilus are curious from their resemblance of Hymenopterous insects.

On the cover are a few shells, obtained from a pond of stagnant (fresh) water. These \& some from our beach which I picked up last summer are not sent as curiosities, but to convince you of my desire to comply with your wishes, as far as it is in my power.

If you have no use for the insects I shall esteem it a great favour to obtain, through your means, an exchange of specimens with any collectors in your vicinity. You have several insects wh. are desiderata, e. g. Cremastocheilus castanea Knoch., Geotrupes Tityus, F.; Bolitophagus cornutus; Brentus anchorago, \& other species of the same genus; Rhagium inquisitor, F.; Elaphrus riparius; Tipula tritici; $\& c, \& c$. I have not yet found native species of Blaps; but very few of
Dytiscus, of which No. 23 in Box I is the largest; \& but one small Hydrophilus. Those insects which I have sent are such as are the most common here: you can thence form some idea of what my collection must consist.

I am desirous to know whether Xenos Peckii is common with you ; \& whether you have discovered any other species either of Xenos or Stylops. I could in summer obtain any number of Xenos Peckii, but do not know how to prepare them for the Cabinet.

I will now bring this long letter to a close, hoping that you will excuse me if I have trespassed on your time and patience; for I am like a traveller in a strange land, anxious to obtain information, \& the best of guides.

Be pleased, Sir, to accept the best wishes \& grateful acknowledgements of

$$
\begin{aligned}
& \text { Yours, very respectfully, } \\
& \text { T. WiLLIAM HARRIs. }
\end{aligned}
$$

[DRAFT OF REPLY BY THOMAS SAY.]

$$
\text { JAN'y 8th, I } 825 \text {. }
$$

\section{Dear Sir!}

Your interesting letter with the boxes of fine insects came to hand in excellent order by Mr. Fuller, at whose lodging I called several times, but probably owing to his engagements, I saw only once for a few minutes.

With respect to the pinastri I think it highly probable that I have adopted the name from Melsheimers Catalogue without examination since I do not find the insect desc'd in my Mss. Since the reception of y'r letter, I have looked 
for it in vain in Fabr. \& Herbst. Prof. Peck's name may therefore probably be retained.

Although much of Herbst's great work was publ'd long before the Syst. Eleut. yet it contains a great many desc's not noticed by Fabr.

I am very happy to find that I have not publ'd the Stenocorus tridens; after much search I discovered the desc'n of the insect amungst my rejected Mss. with the following note subscribed "It is probable that this is the villosus Fabr. as it agrees very well with his short desc'n." I do not think I have seen any insect that agrees better with the bidens Fabr. than this species, but he attributes to that sp. 2 spines to the extremity of each joint of the antennæ. It may be different from both, in which case Prof. Peck's name of putator must of course be retained.

Your Ægeria fulvicornis, is, I think new ; it is certainly a charming and curious insect. I cannot determine whether the Cicindela be new or only a variety, but I am inclined to the opinion that it is new. I have no unpublished description of a Cicindela.

I agree with you perfectly with respect to latin specific definitions; I do not see the necessity of thus using that language in preference to the French, German or English languages, for I believe that almost every naturalist of any distinction can read a description in either. If any part is to be latinized I conceive it ought to be the history which is always the most difficult to read in a foreign language.

The following is a list of the insects contained in the first box, carefully compared with descriptions of authors, with my Mss. descr's \& with the specimens in my cabinet. [The list is not given.] The contents of the second box I have not yet had time to examine \& compare, but I will attend to them as early as possible.

A new genus has recently been made by Dejean for the Stenocorus cyaneus Fabr. under the name of Desmocerus. It could not be referred to the g's Hargium of Leach, which is not adopted by subsequent writers.

I regret my inability to give you any information relative to the larvæ you mention, my opportunity of becoming acquainted with the changes of insects is at present very limited.

You mention having sent some Marine shells, but I have only received those that are attached to the lid of one of the boxes, \& they are all fresh water; I therefore suppose that there was a package that I have, unfortunately, not received.

Xenos peckii is common here; but I have not seen any other species of the genus or of Stylops. 

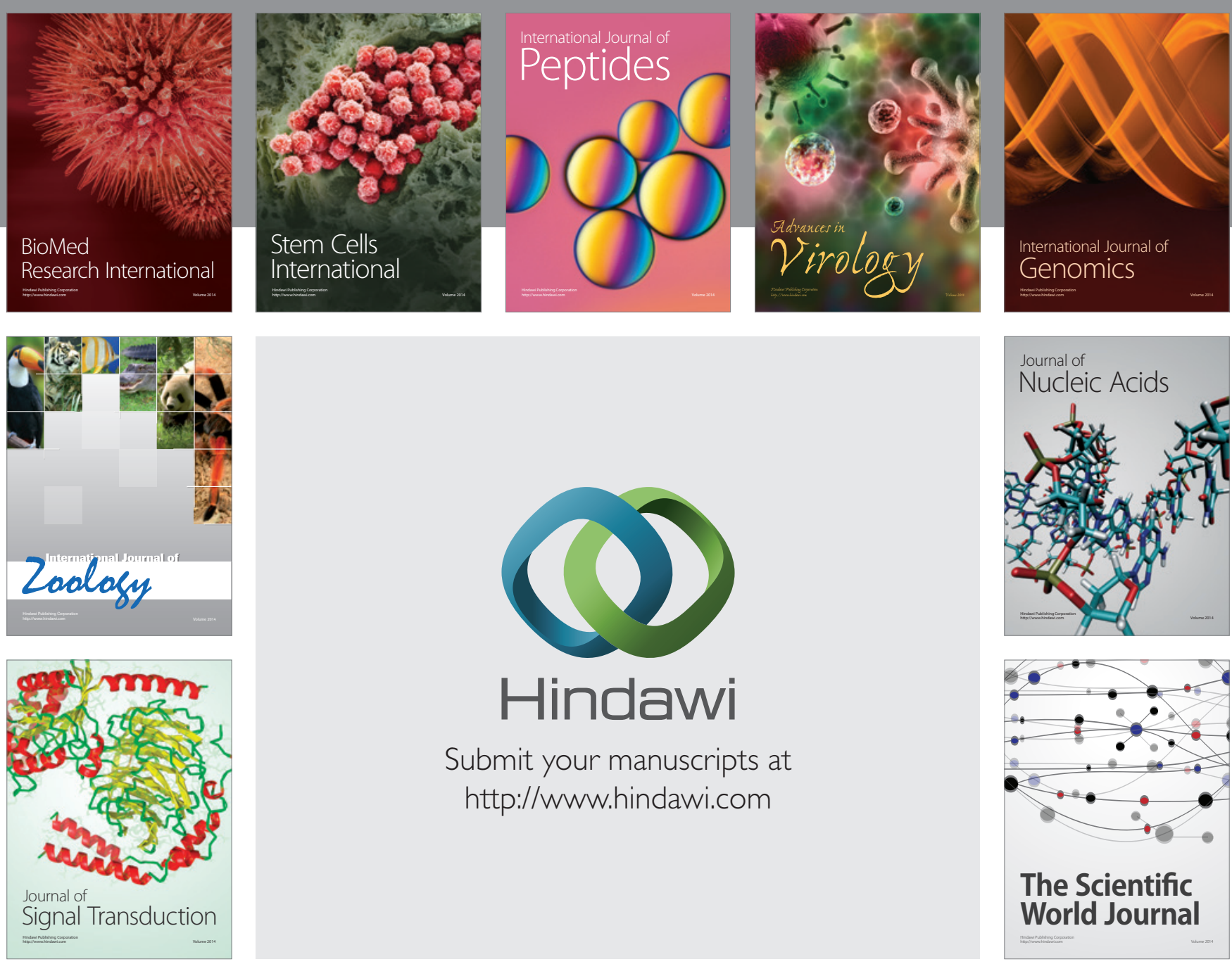

Submit your manuscripts at

http://www.hindawi.com
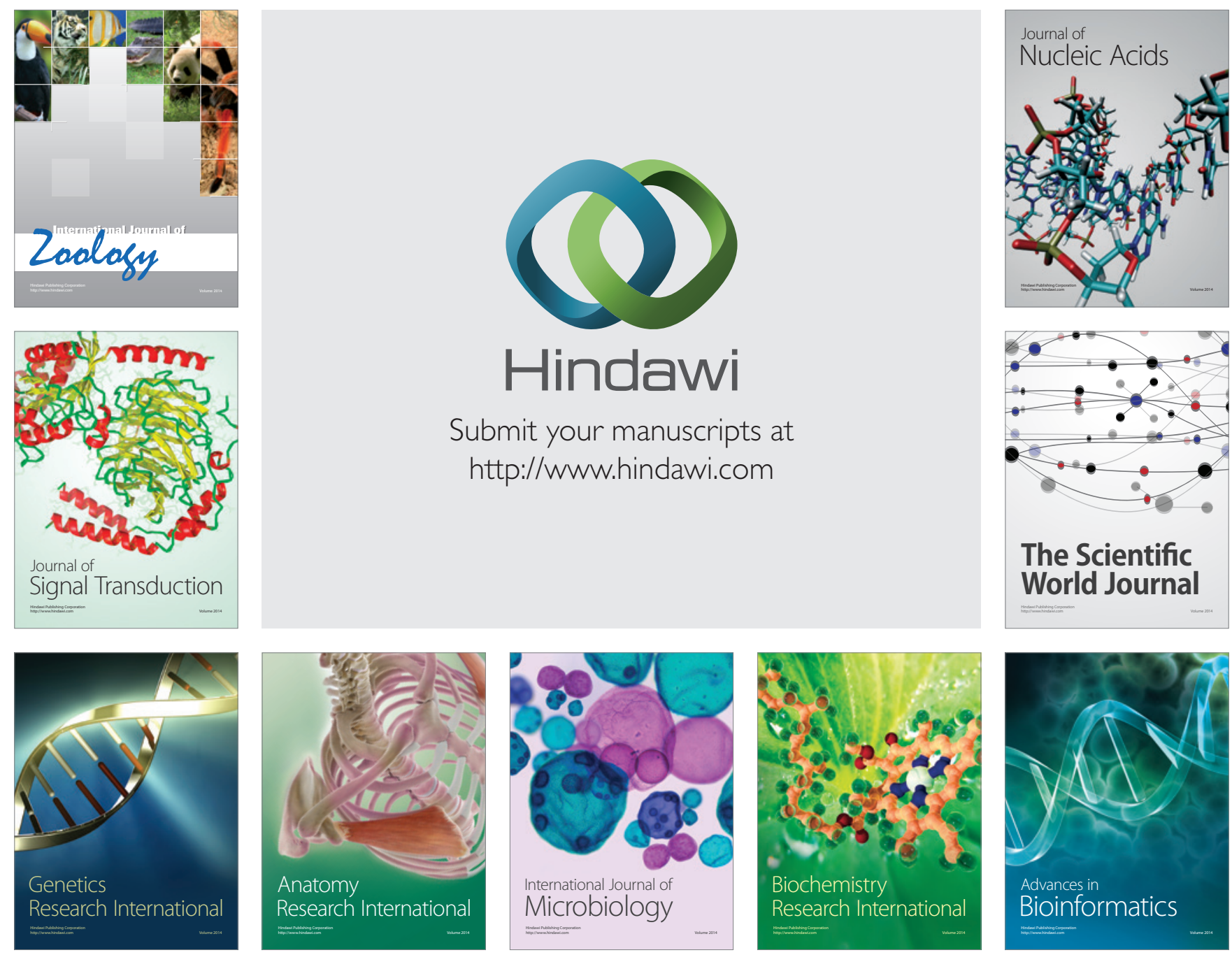

The Scientific World Journal
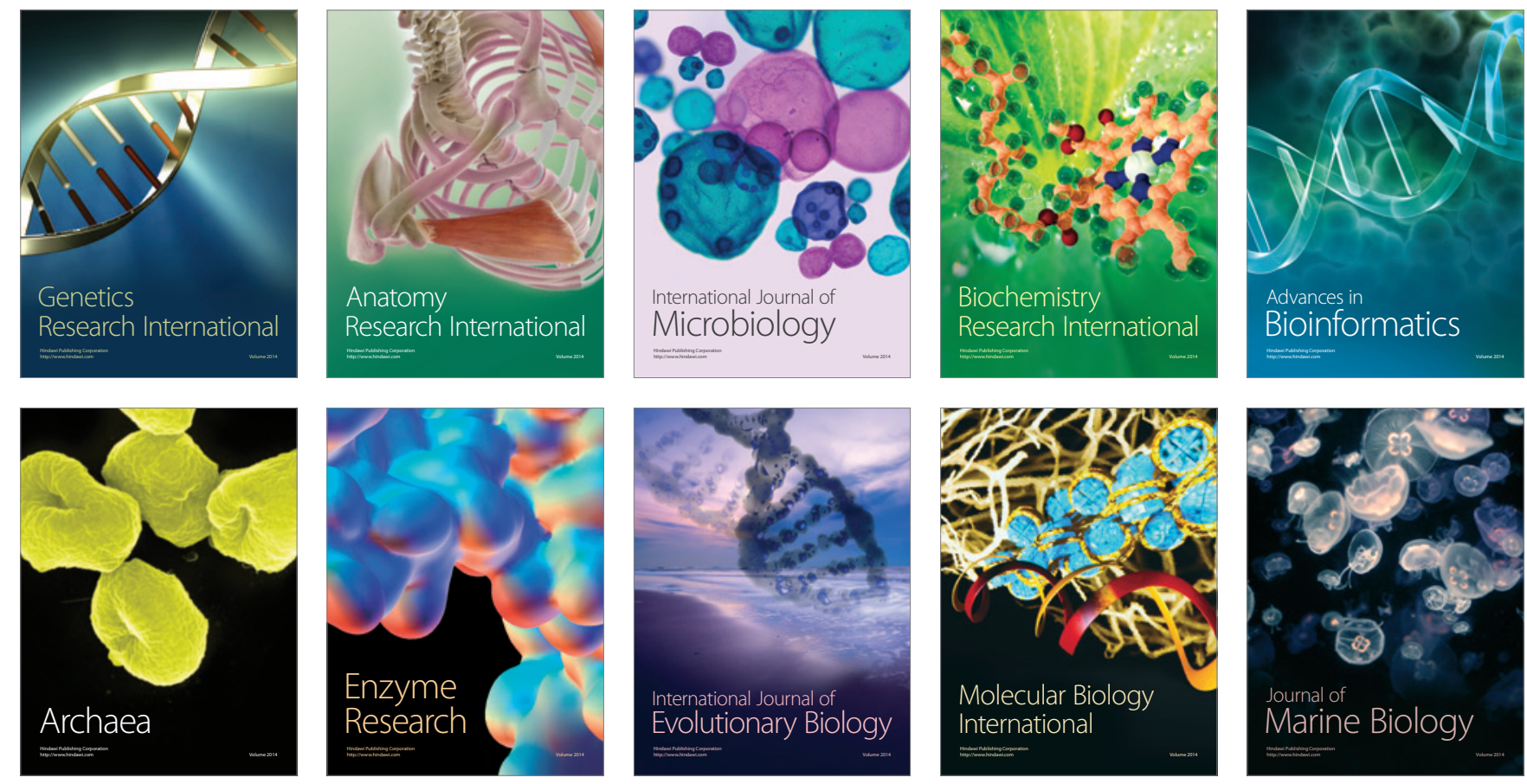